\title{
Lo mediático y lo social: una compleja interacción
}

"Les Stars sont comme les dieux: tout et rien. La
substance divine qui gorge ce rien est l'amour des
humaines. Le vide infini du dieu est aussi richesse infinie, mais cette richesse n'est pas sienne. La star est vide de toute divinité comme des dieux. La star est riche de tiute l'humanité comme les dieux."

- Edgar Morin, Les Stars

\section{RESUMO}

A leitura tradicional da relação estabelecida entre o universo do midiático e a vida cotidiana, traz como tendência enfatizar o caráter ideológico dos massmedia. Os meios de comunicação de massa vêm sendo concebidos como transmissores de uma ideología que coloniza a vida social e legitima as relações de dominação existentes. À margem dessa leitura, cabe uma interpretação do magnetismo cotidiano suscitado pelo midiático a partir das demandas arquetípicas geradas na própria vida social, e que os meios, em última instância, tratariam de satisfazer. Essa leitura, pretende complementar a anterior e desvendar o papel social das constantes antropológicas universais as quais são, na cultura atual, projetadas sobre o universo midiático.

\section{PALAVRAS-CHAVE \\ - ideologia \\ - arquétipos \\ - modernidade}

\section{RESUMEN}

La lectura tradicional de la relación establecida entre el universo de lo mediático y la vida cotidiana ha tenido tendencia a enfatizar el carácter ideológico de los massmedia. Se han concebido los medios de comunicación de masas como transmisores de una ideología que coloniza la vida social y que legitima las relaciones de dominación en ella existentes. Al margen de esta lectura, cabe una interpretación del magnetismo cotidiano suscitado por lo mediático a partir de unas demandas arquetípicas generadas en la propia vida social y que los medios, en última instancia, tratarian de satisfacer. Esta lectura, pretendiendo complementar a la anterior, buscaría, entonces, desentrañar el papel social de ciertas constantes antropológicas universales que ahora son, en el tipo de cultura actual, proyectadas sobre el universo mediático.

\footnotetext{
PALABRAS-CLAVE

- ideología

- arquetipos

- modernidad
}

\section{Enrique Carretero Pasín} IES Chano Piñeiro
- s ya una reiteración afirmar que las sociedades actuales se caracterizan por una fuerte dimensión mediática. Los mass-media, en efecto, configuran aquello que es percibido y asumido como lo real. En otro tiempo, como es bien sabido, la gestación y transmisión de esta definición de la realidad era patrimonio de instancias religiosas o intelectuales. Sin embargo, el auge de los medios de comunicación de masas, a raíz de la segunda guerra mundial, convierte a éstos en instrumentos generadores de unas nuevas formas culturales antaño inexistentes. Así, la impronta de los mass-media se va a encontrar presente en el ámbito de la estructuración de las relaciones interpersonales, en el de las tomas de decisión políticas, en el de las dinámicas socializadoras e incluso en el de la construcción de las propias subjetividades sociales. Se ha insistido sobremanera en cómo el universo mediático diseña unas formas de expresión culturales que son absorbidas e interiorizadas por los individuos, impregnando finalmente el espectro de la vida colectiva. Los medios, se ha afirmado con insistencia en diferentes círculos académicos e intelectuales, manipulan interesadamente la presentación de la experiencia social al servicio de oscuros intereses económicos o incluso políticos. De esta manera, se ha asociado su papel al de un nuevo ejercicio de poder que utiliza unas sutiles estrategias encaminadas al mantenimiento del status quo instituido y, en consecuencia, al fortalecimiento de la conservación de una arquitectura social que alberga unas acusadas contradicciones estructurales. En el horizonte de esta perspectiva, evidentemente, los medios de comunicación serían la verdadera causa a la que achacar una buena parte de un malestar social que se manifestaría bajo la forma de una variada gama de patologías culturales que, en cada vez mayor medida, colonizan los variados plexos en donde se entreteje la vida cotidiana. Es lógico, entonces, que, en este contexto, haya brotado en los últimos años, al margen de las diferentes opciones políticas o ideológicas, una explícita y generalizada condena en términos morales del universo mediático al que se reprocha una buena parte de unos desajustes o desarreglos sociales en otro tiempo aparentemente inexistentes.

No obstante, aceptando previamente el relevante papel asignado a los mass-media en nuestras sociedades, conviene interrogarse acerca de si esta satanización de lo mediático como fuente de la que surgiría un acentuado malestar cultural, en lo que tiene de simplificadora, no estaría ocultando, en realidad, unas complejas dinámicas sociales que estarían operando en la clandestinidad de la vida social y que darían cuenta del seductor magnetismo inspirado por los mass-media en nuestras vidas. A finales de 
los años cuarenta del ya pasado siglo, nacía, en el marco de la teoría sociológica, un discurso crítico en torno a los perniciosos efectos ideológicos derivados de la emergencia de los medios de comunicación. En síntesis, dicho discurso, con una clara raigambre marxista, veía en los medios de comunicación el origen de unas emergentes formas de alienación social anteriormente circunscritas al campo de lo productivo. ${ }^{1}$ En la actualidad, como prolongación de este discurso, se le imputa constantemente a la televisión el ser la causante de la degradación de la cultura y de la educación, a la imagen publicitaria la de ser la estimuladora de un consumismo desenfrenado o a la imagen, en general, de ser el origen de una reducción del horizonte experiencial de los individuos. A partir de un cierto posicionamiento teórico, los medios se han transformado, de esta forma, en un verdadero demonio malévolo que provocaría un variado conjunto de desgraciados fenómenos sociales. Así, desde esta óptica, la anorexia, los accidentes de tráfico, el fracaso escolar, el desinterés cívico y, en general, un ilimitado abanico de recientes patologías sociales, obedecerían, en última instancia, a la cultura mediática.

Ahora bien, lo que deberíamos preguntarnos es si, realmente, en esta reductora y simplificadora identificación de la causa de estas patologías con el universo mediático se nos estaría ocultando, en lugar de aclarársenos, una lógica social difícilmente visualizable cuyo desentrañamiento constituiría el verdadero reto actual de las ciencias humanas y sociales. Este discurso crítico, en lo que atañe a su fácil culpabilización de la imagen mediática, es el que, posiblemente, en lugar de esclarecer pueda llegar a oscurecer el trasfondo de una lógica social que no se deja captar con facilidad para el investigador social. Es necesario sospechar, en suma, de la perspectiva sociológica que convierte a los medios en «chivos expiatorios» de gran parte, sino de la totalidad, de la negatividad social. La cultura occidental, atravesada por un arquetípico y esquemático dualismo positividad/negatividad, heredado del judeo-cristianismo y proyectado en nociones imaginarias tales como bien/mal, cielo/infierno, purificación/pecado, ha ubicado ahora a la comunicación mediática en el espacio de una recurrente negatividad. La tarea sociológica, en lo que tiene de interrogación radical de toda connaturalizada mistificación social, se encuentra obligada, una vez reconocida la trascendencia cultural del universo mediático, a problematizar e ir más allá de un discurso crítico que, si bien en un determinado momento histórico ha sido una indudable fuente de inspiración para una fidedigna comprensión de las claves de la vida social, en la actualidad no parece ser la herramienta más adecuada para interpretar unas nuevas realidades sociales.

Parece, pues, oportuno abordar el papel social de los mass-media desde una nueva óptica. Para ello, conviene, en primer lugar, dislocar el esquema conceptual tradicional que ha concebido lo cotidiano como un mero espacio de receptividad de una ideológica cultura mediática; ${ }^{2}$ lo que podríamos denominar como un paradigma unidireccional de interpretación de lo mediático. Luego, sería necesario introducirse en un análisis más complejo, a saber: el de cómo lo cotidiano llega a actuar, en una u otra dirección, sobre lo mediático; lo que catalogaríamos como un paradigma bidireccional.

\section{Los presupuestos teóricos subyacentes en el paradigma unidireccional de comunicación}

El modelo de unidireccional de comunicación se apoya, básicamente, sobre dos presupuestos sociológicos:

1. Los medios de comunicación transmiten una interesada ideología al servicio de determinados intereses de ciertos grupos sociales y cuya función es legitimar el orden social vigente;

2. La vida cotidiana se entiende como un espacio plenamente colonizado por la ideología transmitida por los medios.

PRESUPUESTO 1 Este presupuesto recalcaría, en última instancia, cómo la sociedad alberga unas contradicciones sociales internas que son mantenidas a través de los mass-medias. Para esta perspectiva de análisis social, los medios de comunicación social serían los encargados de construir lo que Antonio Gramsci denominara en su momento como una hegemonía cultural, es decir, una organización global del significado de la experiencia social asumida como certidumbre, una cultura que, en su totalidad, es experimentada de forma connaturalizada y aproblematizada. ${ }^{3}$ Desde este posicionamiento, en realidad, los medios de comunicación de masas vendrían a reemplazar, de este modo, al papel antaño desempeñado por lo que Louis Althusser acuñó con la terminología de Aparatos Ideológicos del Estado. Althusser afirmara, a este respecto, que la escuela y la familia eran las instituciones sociales destinadas a vehiculizar una homogénea ideología dominante capilarizada por todo el cuerpo social y aceptada como una evidencia incuestionable por los grupos en este caso clases sociales - dominados. ${ }^{4}$ Así, a su juicio, la fijación de los individuos a la arquitectura social pasaba por el papel asignado a estos Aparatos Ideológicos en la dinámica social. No obstante, en este posicionamiento, la cultura mediática, aún reconociéndose en este marco teórico, introduciría un novedoso sistema de legitimación. La garantía de adhesión al orden social vigente, que Althusser había localizado con anterioridad en los Aparatos Ideológicos del Estado, daría paso, entonces, a unos aparatos de representación; a una construcción de realidades sociales encaminada a la edificación de un interesado espacio de visualización social. ${ }^{5}$ De ma- 
nera que la aquiescencia generalizada de los individuos a una estructura social que acogería fuertes contradicciones vendría respaldada ahora por el preponderante papel desempeñado por el régimen mediático y en especial, como hemos desarrollado en otro contexto, por los Imaginarios sociales. ${ }^{6}$ Ahora bien, mientras los antiguos Aparatos Ideológicos del Estado operaban en el orden de los valores y de las creencias compartidas, la cultura mass-mediática lo haría en el de la presentación de realidades sociales. La mediatización de la cultura, como ha señalado John B. Thompson, ${ }^{7}$ implicaría, en suma, un desplazamiento de las antaño formas tradicionales de legitimación ideológica al novedoso ámbito de los medios de comunicación social.

Este marco teórico, pues, entendería el papel social de los mass-media, guardando fidelidad a la tradición del marxismo crítico, a partir de sus efectos ideológicos. Ideología concebida, en su sentido genuinamente formulado en los textos de Karl Marx, como una deformada versión de la realidad social en la que se omitirían las condiciones reales de existencia en la que se desenvuelven los individuos. Pero, además, una deformación que es estimulada intencionadamente por los grupos sociales dominantes y que finalmente es aceptada como algo connaturalizado. Recordemos como para Marx «Las ideas de la clase dominante son las ideas dominantes en cada época». ${ }^{8}$ En el contexto histórico en el que se enmarcaba la crítica marxiana de la sociedad, la religión, la filosofía especulativa y la ciencia de la Economía Política desempeñarían las funciones que Marx le atribuía a la ideología. La ideología, en todo caso, conviene subrayarlo, es aquello que posibilitaría una justificación de la dominación social.

Las modificaciones estructurales del capitalismo, sin embargo, conllevarían un declive de las instancias ideológicas tradicionales y la emergencia de unas nuevas estrategias ideológicas. La legitimación de la dominación en el capitalismo tardío, entonces, recurriría a unas nacientes formas de ideología ligadas al papel de los mass-media. La idea central sobre la que gravita este posicionamiento teórico es que el capitalismo, en una nueva fase histórica, operaría por medio de una dominación simbólica estrechamente vinculada al consumo mediático y encaminada a la manipulación de las conciencias. Así, Theodor Adorno y Max Horkheimer van a establecer, ya en 1947, una ligazón entre la industria cultural propia de la cultura de masas y las emergentes formas de dominación, anticipando buena parte de los análisis críticos posteriores en torno a los medios de comunicación. En un tono apocalíptico, señalan: «Toda cultura de masas bajo el monopolio es idéntica, y su esqueleto - el armazón conceptual fabricado por aquél - comienza a dibujarse. Los dirigentes no están ya en absoluto interesados en esconder dicho armazón; su poder se refuerza cuanto más brutalmente se declara. El cine y la radio no necesitan ya darse como arte. La verdad de que no son sino negocio les sirve de ideología que debe legitimar la porquería que producen deliberadamente». ${ }^{9}$ Para comprender el cómo y el por qué persiste la explotación y la dominación en un estadio avanzado del capitalismo es necesario, para autores como Jean Baudrillard o Guy Debord, descifrar el papel de la cultura mediática. En suma, desde este paradigma teórico, los medios se van a identificar inexorablemente al ejercicio del poder y a la dominación social.

PRESUPUESTO 2 Este presupuesto incidiría en cómo la ideología mediática es absorbida totalmente por los individuos, sin ningún tipo de resistencia o rechazo frente a ella. Los medios construirían una imagen de la realidad que pasaría a ser, así, la realidad. Lo cotidiano, desde esta perspectiva, es un mero receptáculo de acogida de una heterogénea ideología elaborada por los medios y propagada a través de éstos. De modo que la cotidianeidad no sería más que un reflejo de lo mediático asumido de manera connaturalizada. En esta lectura de lo social, la vida cotidiana sería una vida, en última instancia, absolutamente prefabricada y manipulada desde instancias externas. ${ }^{10} \mathrm{La}$ única interpretación del mundo posible, entonces, sería aquella previamente diseñada en la industria mediática y orientada, como diría Baudrillard, hacia un intencionado consumo de signos. ${ }^{11}$ Es una concepción de lo cotidiano entendido como una reproducción de unas representaciones del mundo ajenas y nunca nacidas de éste. Así, la vida cotidiana estaría totalmente seducida y subordinada a los estilos de vida suscitados y propugnados por los mass-media. Lo cotidiano, pues, es un espacio pasivo colonizado por la ideología mediática; por decirlo en términos marxistas clásicos, es el espacio de una falsa conciencia. Se acepta que la vida cotidiana es una vida falseada, controlada y administrada desde las instancias de poder mediático, y que los individuos son víctimas propiciatorias de un engaño generalizado.

De manera que, en esta perspectiva, se presupone que la mayoría de los individuos no dispone de los recursos intelectuales necesarios para reconocer la dominación mediática ni su papel como meros receptores manipulados de ésta; se presupone, en suma, que éstos ignoran que lo que asumen como evidencia real es una construcción mediática. Es una idea de la sociedad contemplada como un espacio de consumo de unas imágenes mediáticas que son impuestas como un código de sentido único. Llevada hasta sus últimos extremos esta tesis, difícilmente nos encontraríamos capacitados para discernir cuando determinadas vivencias o experiencias individuales o colectivas de libertad, de imaginación creadora o de autonomía personal emanan espontáneamente del cuerpo social de cuando son derivadas de elaboraciones previamente diseñadas interesadamente por la cultura mediática. En definitiva, 
¿Cómo podríamos saber si la libertad, experimentada como tal, es algo genuino o algo construido socialmente como una controlada y planificada forma de evasión? La sospecha de una fabricación mediática se extiende de tal modo a todo lo social que incluso toda respuesta a ella no es inmune a dicha sospecha. Pero, también, asociado a lo anterior, y lo que es más importante: ¿No se estaría negando, en esta versión de lo cotidiano, la existencia de una sabiduría escéptica connatural a lo popular y fuertemente arraigada en lo cotidiano? $\mathrm{O}$, para decirlo de otro modo, ¿No se estará asumiendo, como principio, que el pueblo está incapacitado por si mismo para detectar un mundo falseado mediáticamente? Lo que denominamos como paradigma unidireccional de comunicación no permite vislumbrar, así, unas disidencias larvadas frente a lo mediático, una aparente seducción que, sin embargo, esconde un soterrado descreimiento cuando no una manifiesta ironía o sarcasmo.

La vida cotidiana, en relación con lo anterior, sería una vida absolutamente presa de una completa alienación social, es decir, de una desnaturalización y cosificación de las subjetividades sociales, de las formas de socialización interpersonal y de las estructuras simbólicas procuradoras de significación. En este marco teórico, se da una consustancial identificación entre lo mediático y la alienación cotidiana. Se le reprocha a la ideología mediática, en suma, el ser aquello que impide que el mundo sea como en realidad debiera ser, que bloquea la consecución de un mayor grado de perfección social en sus diferentes vertientes éticas, políticas o estéticas. Pero la interrogante a la que nos debiéramos enfrentarnos en este caso sería: ¿La alienación es realmente una responsabilidad de lo mediático o, por el contrario, tiene su origen en un despersonalizador programa de vida instaurado por la modernidad en donde el individuo es concebido como un mero elemento de un engranaje tecno-productivo? ¿Concentrando nuestra culpabilidad sobre lo mediático no estaremos olvidando que éste es uno de los pocos espacios intersticiales de fuga de los que dispone el individuo para evadirse de un mundo sumamente hostil? La insistente desviación de nuestra atención hacia la repulsa en torno a lo mediático ¿No estará ocultando un problema de más hondo calado? ¿No le estará pasando desapercibido a ésta que aquellos que Walter Benjamín denominaba como «los vencidos por la historia», es decir los seres anónimos a los que la lógica tecno-productiva moderna les ha encadenado a una vida que no es vida, tienen una acuciante necesidad de alteridad que le es proporcionada por el universo mediático? Es este urgente deseo de evasión, de proyectarse en un mundo diferente al mundo real, el que, quizás, esté catapultando en buena medida el magnetismo social de lo mediático. Recordando el análisis de Marx acerca de la religión en La cuestión judía, no se trataría tanto de criticar el fenómeno religioso en si mismo - en este caso lo mediático - como el carácter contradictorio de la vida que demanda una urgente inversión del mundo. «No afirmamos - dice Marx - que los ciudadanos deban sacudir su limitación religiosa para abatir sus barreras seculares. Sostenemos, por el contrario, que tienen que destruir sus barreras temporales si quieren salir de su limitación religiosa». ${ }^{12}$

\section{El modelo bidireccional: una alternativa teórica para comprender la comunicación}

Este modelo nos posibilita un acercamiento a la relación existente entre los mass-medias y la sociedad más allá de la reductora perspectiva de una manipulación mediática. En lugar de aceptar que los medios de comunicación fabrican una falseada realidad que se superpone intencionadamente sobre la experiencia social, incidiría en cómo y por qué lo social demandaría a los medios determinadas imágenes. Aún asumiendo la fuerza social de la imagen mediática, es preciso reconocer la existencia de un proceso inverso: el de cómo los medios ofertan unas imágenes que tratan de responder a unas exigencias emanadas del cuerpo social. El modelo unidireccional había absolutizado una idea de lo social en donde se primaba una conspiración mediática externa. El modelo bidireccional, por el contrario, buscaría mostrar que, aun existiendo una evidente influencia de los medios sobre lo social, éste último también solicita a los medios que éstos le suministren algo. El reto sociológico radicaría, entonces, en desvelar qué es aquello que lo social exige a los medios y por qué lo exige. De este modo, quizás estemos en condiciones de desentrañar el por qué ciertas imágenes mediáticas adquieren un fuerte arraigo social, mientras que otras son, por el contrario, totalmente despreciadas. Si el primer modelo concebía a lo social como víctima de lo mediático, el segundo trataría de enfatizar que lo social, en última instancia, también posee un oscuro dinamismo interno que reclama algo de lo mediático. Este último modelo, en suma, permite acceder a una visión más compleja de las relaciones establecidas entre el universo mediático y la vida social.

Para una comprensión fidedigna de la lógica que rige este modelo es preciso, sin embargo, reconsiderar una axiomática heredada de la tradición culturalista e historicista. A raíz del siglo XIX, buena parte de las concepciones sociológicas se volcarán en el proyecto de disolución de la categoría de naturaleza como una construcción socio-histórica. Desde entonces, todo lo anteriormente aceptado como naturaleza es ahora historia y cultura, o en su última variante construcción mediática. Al margen de esta tradición hegemónica en Occidente, las líneas de investigación socio-antropológicas abiertas por Karl Gustav Jung, Mircea Eliade o Gilbert Durand nos permiten radiografiar un componente arquetípico, propiamente trascendental y transhistórico, que se 
reactualizaría permanentemente bajo modulaciones diversas y en diferentes contextos históricos. ${ }^{13}$ Lo arquetípico, así, nos retrotraería a ciertas constantes antropológicas universales que adoptarían unas figuraciones históricas específicas, propiciando, de este modo, conciliar lo uno y lo múltiple de toda sociedad. Lo que nos interesa recalcar es que la pervivencia de los arquetipos nos revela la existencia de unos depósitos antropológicos que van a persistir más allá de las distintas concreciones culturales específicas.

El dinamismo de esta precondición arquetípica, que actuaría en las profundidades de lo social, nos permitiría desvelar el por qué unas imágenes mediáticas suscitan una fuerte atracción y otras, por el contrario, una indiferencia o rechazo. Desde esta perspectiva, la seducción mediática, entonces, cristalizaría en la medida en que sea capaz de ensamblarse con una previa demanda arquetípica preexistente. Esto es especialmente manifiesto en el caso de las imágenes estereotípicas alentadas por la publicidad, las cuales, como ha mostrado A. Sauvageot, ${ }^{14}$ son eficaces en tanto en cuanto logren entroncarse con una recurrente y subyacente carga imaginaria y con su trasfondo arquetípico. Existe, pues, una imbricación entre el estereotipo proyectado por la imagen mediática y un fondo arquetípico; lo que puede llegar a explicar la receptitividad social de los media más allá de una manipulación ideológica. En efecto, hay un profundo territorio en la vida social que el modelo unidireccional no llega a captar, y que estaría provocando el fuerte arraigo social de la imagen mediática. En esta lectura de la dialéctica existente entre los media y la sociedad se abandona el pesimismo crítico resultante de la unívoca identificación de los medios con una función ideológica, para, de esta manera, incorporar nuevos elementos que puedan dar cuenta de la atracción social suscitada por aquellos. Las demandas arquetípicas, en otro tiempo o en otras culturas proyectadas sobre un determinado espacio social, son ahora, en una cultura propiamente mediática, lógicamente proyectadas sobre el espectro mediático. En definitiva, este modelo nos posibilita percibir cómo también lo social guarda una subterránea complicidad con los efectos sociales derivados de los mass-media, cómo también aquél está, consciente o inconscientemente, interesado en mantener y utilizar, como a veces se olvida, el universo mediático. Es el victimismo implícito en el modelo unidireccional el que nos impide cerciorarnos de esto. La inquietud sociológica, entonces, debería orientarse, fundamentalmente, hacia la elucidación de qué es aquello que lo social demanda de los medios, o dicho de otro modo, qué es lo que los medios realmente ofrecen a la sociedad.

Vamos a centrar nuestra atención prioritaria en torno a cuatro elementos arquetípicos, a nuestro juicio, esenciales para comprender el magnetismo social de los media:
1. El mundo de lo imaginario;

2. El mito;

3. La sociabilidad;

4. Lo no-racional.

EL MUNDO DE LO IMAgINARIO El trabajo de Durand, Las estructuras antropológicas de lo imaginario, inaugura, a comienzos de los años sesenta del pasado siglo, una línea de investigación encaminada al reconocimiento de lo que este autor denomina como una fantástica trascendental. A juicio de Durand, existiría una condición antropológica mediante la cual el hombre busca transfigurar la realidad a través de la apelación a un mundo imaginario. Ésta es la faceta eufemizadora propia del ser humano, por medio de la cual el hombre necesitaría crear realidades imaginarias, irreales, ficticias, que abastecen de un ensueño reimaginante su vida cotidiana. ${ }^{15} \mathrm{El}$ hombre, sostiene Durand, posee una predisposición universal y arquetípica destinada a edificar mundos imaginarios; es un ser potencialmente creador que genera espontáneamente ficciones para amplificar y trascender su realidad. A través de la imaginación, se manifiesta una insubordinación, en suma, ante los dictados de la realidad. De modo que la imaginación no es una mera facultad psicológica que propiciaría una evasión de lo real, sino, más bien, uno de los rasgos genuinamente constitutivos de la naturaleza humana. Durand, siguiendo la línea de pensamiento auspiciada por el islamista Henri Corbin, ${ }^{16}$ atribuye, entonces, a la imaginación un carácter propiamente ontológico, concibiéndola como un ansia universal por trascender la facticidad de lo real. Lo imaginario nacería del anhelo arquetípico por reencantar la realidad a través del ensueño, por desdoblar lo real en lo ficcional. Así, de este modo, la esencia de la literatura, como la del arte en general, consistiría, precisamente, en introducir más vida en una desencantada cotidianeidad. En las culturas que preceden a la modernidad, como destacara Rogerd Bastide, ${ }^{17}$ el mundo imaginario y el mundo real se complementaban mutuamente y guardaban una estrecha relación de ósmosis. La específica escisión cultural producida en Occidente entre estos dos mundos va a ser la que propiciará, a partir de entonces, una necesidad de que lo real se alimente y se reequilibre a partir de lo imaginario. Hay un estatuto propio, pues, de la ilusión en la vida social que no debiera identificarse simplificadoramente a lo ideológico, sino a un elemento genuinamente constitutivo de toda existencia social. ${ }^{18}$

En los años sesenta del pasado siglo, los trabajos de Edgar Morin se han orientado a estudiar la cultura mediática a partir del presupuesto según el cual las sociedades demandarían un mundo imaginario que alimentaría de ilusión la vida cotidiana. Así, Morin ${ }^{19}$ muestra como la fascinación suscitada por el cine vendría dada por su capacidad para introducir la fantasía en la experiencia social. El cine, como 
fábrica de sueños, genera irrealidades que acaban siendo finalmente reales, entremezclándose y confundiéndose con la realidad cotidiana. Por eso, Morin nos descubre cómo en la cultura de masas la necesidad arquetípica de salirse de lo real mediante la ensoñación, de proyectarse en mundos imaginarios, se va a manifestar en las salas cinematográficas. De un modo similar, los productos de la cultura de masas, a su juicio, nos evidencian una dialéctica constante entre lo imaginario y lo real. ${ }^{20}$ Dichos productos propondrían modelos e imágenes imaginarias en torno a las cuales se canalizarían los mecanismos antropológicos de proyección e identificación. La cultura de masas, afirmará Morin, como antaño ocurría con la magia, inviste de ilusión y ensueño la vida banal de cada día actuando como verdaderos «modelos estéticos» que liberan y proyectan deseos, aspiraciones y angustias sepultadas por las coacciones de lo real. Así, en este contexto, lo imaginario se transforma en una «estructura antagonista pero al mismo tiempo complementaria de lo real».21 A través de los mecanismos de identificación y de proyección, la cultura de masas impulsaría una evasión y al mismo tiempo una purificación de los fantasmas individuales y colectivos vetados por el orden social, constituyendo un verdadero exorcismo de la realidad. De ahí que, según Morin, el éxito de este tipo de cultura radique en su apelación al componente infantil que late siempre en todo ser humano, tal como mostraría el recurso al Happy end con su deseo de eternidad y felicidad plena como signo de un ansia de trascendencia de lo real.

Esto explicaría el doble movimiento de lo real a lo imaginario y viceversa de lo imaginario a lo real, la doble direccionalidad, que se produce en la lógica de la cultura de masas. ${ }^{22}$ La propuesta de Morin nos permite revelar el entre-juego constante y la amalgama que se da entre lo imaginario y lo real en toda sociedad. Ocurre que, en la cultura mediática, esta dialéctica de lo imaginario y lo real se vehiculiza en torno a imágenes y modelos suscitados por aquella. En suma, es ahora la cultura mediática la que oferta patrones de satisfacción a la originaria demanda imaginaria emanada tanto del individuo como de la sociedad. Esta transfiguración de lo real en lo imaginario no debiera ser identificada, simplificadoramente, a una evasiva alienación provocada interesadamente por un determinado sistema económico. Su génesis reposa, insistimos, en una condición propiamente antropológica e independiente de cualquier modelo social. En todo caso, la crítica a la alienación debiera dirigirse a un mundo racionalizado, cosificado y desencantado que genera una acuciante necesidad de transfiguración. El apego a lo mediático bien podría se interpretado como una reacción frente un mundo reificado, como un verdadero ejercicio de contra-alienación que trata incorporar un mundo de ensueño alternativo al real, como un anhelo por recuperar la magia reprimida por una civilización con- sagrada a la racionalización y a la objetivización. En este punto, pensamos, reposa el magnetismo alentado por la imagen mediática y en especial por la publicidad. Así, puede llegar a establecerse una similitud entre el eco social de la imagen publicitaria y la religión. Ambas sirven para canalizar los deseos más profundos del ser humano, promoviendo un ansia, en última instancia, de inmortalidad; aunque ahora, en el caso de la imagen publicitaria, desposeída de transcendencia. La imagen mediática estimula, pues, una desbordada fusión de imaginario y realidad, pero orientándose, en este caso, hacia lo más proxémico.

Una experiencia cotidiana rutinaria y monótona tiene necesidad de desdoblarse en lo imaginario, de tal suerte que, parafraseando a Michel Maffesoli, la proyección en la imagen mediática es un auténtico «hiato irracional» en un reinante mundo unidimensional, convirtiéndose en una fisura en la lógica productivista auspiciada en la modernidad. ${ }^{23}$ Asimismo, la seducción que ha suscitado en los últimos años el mundo virtual desplegado en las nuevas redes de comunicación puede ser interpretada como un azaroso intento por encontrar en mundos imaginarios aquello que la realidad circundante no ofrece. ${ }^{24}$ La fantasía que la cultura mediática transmite por lo cotidiano cumple la función de ofertar sueños a aquellos que son presa de una reificada realidad. Desvinculándonos de fariseos juicios morales, casi siempre promulgados por aquellos que se encuentran socialmente ubicados al margen de la lógica tecno-productiva moderna, la ficción mediática puede llegar a ser, paradójicamente, un espacio de reencantamiento de un mundo desencantado, una duplicación del mundo que permite hacer más llevadera una vida anodina. Por eso, en este sentido, cabe comprender cómo ante un exceso de arraigo a lo mediático que haría peligrar el funcionamiento de la lógica productivista, el poder responde siempre, $\mathrm{cu}-$ riosamente, con un discurso de reprobación moral. En suma, el poder reconoce que la imagen mediática atesora una potencial facultad capaz de violentar la lógica tecno-productiva moderna; y precisamente por ello trata de gestionarla e impedir que traspase los límites por aquel prediseñados. Cuando la imagen mediática amenaza con traspasar estos límites, es cuando la condena moral entra en juego.

El MITO Como bien ha mostrado Roland Barthes, el mito puede, en efecto, ser una forma de ideología, un «habla despolitizada». ${ }^{25}$ Pero, en contra de lo que pensaba éste, no necesariamente. La naturaleza del mito no se constriñe a una mistificadora deshistorización de lo real. El mito nace del despliegue creativo de la imaginación, surge de una condición fabuladora consustancial al ser humano que, al decir de Henri Bergson, consistiría en «fabricar espíritus y dioses». ${ }^{26} \mathrm{El}$ hombre edifica mitos para hacer frente, nos dice Bergson, a la incertidumbre y a la imprevi- 
sibilidad que acompaña a la vida. El mito proporciona una seguridad y confianza que contrarresta la amenaza permanente del azar. La lógica del mito transita, además, por territorios ajenos a lo racional, anclándose en lo propiamente vivencial y experiencial. Por eso, el ser humano transforma espontáneamente lo real en mito, mitificando siempre su mundo circundante. Pero, también, es un ser que necesita vivir impregnado en lo mitológico y alimentarse de éste. Como es bien sabido, los mitos poseían en la antigüedad un carácter cosmogónico, eran narraciones que, en un tono de leyenda, trataban de dar cuenta de las grandes interrogantes relativas al origen y a las finalidades individuales y colectivas. Es más, puede decirse que todo grupo social descansa sobre un mito fundacional que le sirve como cemento colectivo y le procura una identidad. Asimismo, el mito guarda, en este sentido, una analogía con la religión en lo referente a la ruptura con la temporalidad cotidiana y a la apertura al orden de lo atemporal. «No siendo la mitología más que la corriente de religiosidad latente, la máscara de Dios que legitima por abajo la experiencia del mundo». ${ }^{27}$

Uno de los rasgos genuinamente distintivos de la modernidad, como han diagnosticado Adorno y Horkheimer, ha sido el proyecto de disolución del mito en favor de una racionalidad científico-técni$\mathrm{ca}^{28}$ «Es cierto - afirma Morin - que la razón debe criticar al mito, pero no disolverlo. Si cree haberlo disuelto, entonces es ella la que se ha convertido en mito». ${ }_{29}$ No obstante, pese a ello, el arquetipo mítico ha logrado sobrevivir y se ha metamorfoseado bajo una figura propiamente sociogónica, ${ }^{30}$ es decir en un abanico de micromitologías que anidan en la cotidianeidad y que espolean comportamientos colectivos. Mircea Eliade ha sabido ver cómo en la sociedad moderna occidental, aparentemente secularizada y desmitologizada, se deja traslucir un abigarrado y heterogéneo conjunto de hierofanías, es decir de mitos que, a pequeña escala, pueblan la vida cotidiana. ${ }^{31}$ El mito se desprende, así, de una dimensión trascendente, para encarnarse en figuras o comportamientos propiamente profanos y proxémicos, tales como el mito de Superman, ciertos personajes de la novela policíaca, el culto al automóvil o la obsesión por el éxito. Por medio de estas hierofanías, nos dice Eliade, se nos manifiesta «cómo el hombre moderno conserva aún al menos ciertos residuos de un comportamiento mitológico». ${ }^{32}$ En ellas, se adivinaría una acuciante necesidad de rebelión contra el tiempo histórico y de inmersión en un tiempo diferente, ya sea extático o imaginario; así como un intento de recobrar una vida vivenciada con una genuina intensidad. La huella del mito late, pues, en la cultura contemporánea. De manera que, como afirma Raymond Ledrut, la paradoja resultante del proceso de desmitologización es que, curiosamente, todo en cualquier tiempo y lugar puede potencialmente devenir en hierofanía, durable o transitoria, descubriéndosenos el rostro del mito en su forma presente. ${ }^{33}$

Así pues, el arquetipo mítico nos muestra como un elemento arcaico, supuestamente denostado y superado por el espíritu racionalista y progresista que impregna la mentalidad occidental desde el siglo XVIII, recobra un destacado papel en las sociedades contemporáneas y pasa a formar parte constitutiva de sus ritualizaciones cotidianas.

En lo concerniente especificamente a la cultura mediática, habría que distinguir, como hace Ignacio Gómez de Liaño, la dinámica de los grandes mitos una macrodinámica mítica - de una microdinámica: «reducidas organizaciones de imágenes revestidas de sentimientos con las que se busca espolear y condicionar la conducta, como ocurre de una manera tan ubicua en las sociedades contemporáneas, merced a la publicidad y la propaganda».$^{34}$ En esta dirección, Edgar Morin ha estudiado la remitificación del mundo que se produce en el culto a las estrellas cinematográficas. La relación que los hombres mantienen con ellas, dice Morin, es equiparable a la existente en otro tiempo con los Dioses. La devoción y veneración en torno a las estrellas cinematográficas mostraría un vestigio de religiosidad, ahora profana, que busca colmar, como antaño ocurría con los dioses de los panteones antiguos, el ansia de inmortalidad y la sed de absoluto que anida en todo ser humano. ${ }^{35}$ El mito estimulado por la cultura de masas no es, recalca Morin, una simple mistificación ideológica, puesto que se enraíza en una demanda antropológica y arquetípica que trata de ser ahora colmada a través del universo mediático. Gillo Dorfles, en una línea similar a la de Morin, ha revelado también la existencia de un componente mitopoyético en la cultura de masas; una restitución del valor simbólico y mitológico que se materializaría en sus nuevos iconos. ${ }^{36}$ De modo que, es importante señalarlo, el mito mediático despierta y redescubre la predisposición arquetípica que había sido previamente soterradas por una monovalente versión racional del mundo instaurada por la modernidad, apelando al componente a-racional que pervive, en estado más o menos latente, en toda cultura. Por eso, como ha apuntado Gómez de Liaño, las nuevas micromitologías vinculadas a las industrias audio-visuales no debieran ser consideradas «como islotes de ignorancia, infantilismo o religiosidad ya superados, sino que, muy al contrario, han surgido de los plegamientos orogénicos que han dado lugar a la modernidad en sus aspectos económico-sociales y urbanos. Si aun así queremos todavía considerarlos como fenómenos de infantilismo, ignorancia y religiosidad, hay que decir en seguida que la fisonomía de estos fenómenos es muy otra a la que pudieron tener en otros tiempos». ${ }^{37}$

En suma, es necesario percibir como el fuerte arraigo social de la cultura mediática se haya estrechamente ligado a una previa demanda de lo social por 
remitologizar un mundo previamente desmitologizado. Los medios de comunicación abastecen de mitos - y lógicamente los utilizan también interesadamente para perniciosos fines -, pero, no lo olvidemos, porque en el corazón de la vida social late un profundo anhelo por recobrar lo mítico. Hasta la instauración histórica de la modernidad, las sociedades mantenían una ósmosis constante entre lo real y lo mitológico. A raíz de la época moderna, se fractura esta ósmosis, pero esto no ha significado la disolución del subyacente arquetipo que demanda lo mitológico. En una cultura dominada por los massmedia, este residuo arquetípico retorna sobre un nuevo escenario social, alimentándose ahora de nuevos rostros y figuraciones.

LA SOCIABILIDAD Georg Simmel, a comienzos del pasado siglo, ha tenido la virtud de mostrarnos cómo en todo grupo social se generan unas «gacciones recíprocas», unas interacciones entretejidas entre individuos, que conforman una especial ligazón comunitaria. Estos procesos socializadores gestan un peculiar espíritu de congregación, así como un anhelo por singularizarse y delimitarse con respecto a otras comunidades. De este modo, Simmel nos descubre la existencia de la forma, una recurrencia o invarianza que estaría subyaciendo en la génesis y cristalización de los diferentes grupos sociales. La forma sería la socialización, una constante universal y transhistórica que se plasmaría en distintas concreciones culturales. «Por tanto, la socialización es la forma que se realiza de incontables manera diferentes en las que va creciendo la unión de los individuos en razón de aquellos intereses sensitivos o ideales, momentáneos o duraderos, conscientes o inconscientes, que empujan causalmente o arrastran teleológicamente y que se realizan dentro de esta unión».38 $\mathrm{De}$ manera que el vínculo de reconocimiento societal, para Simmel, descansaría en unos movimientos pulsionales socializadores que engendrarían efectos de reciprocidad entre los individuos y de los cuales surgiría un sentimiento de comunidad. La noción de forma simmeliana permite comprender cómo, más allá de la multiplicidad de expresiones comunitarias, estaría latiendo permanentemente un lazo propiciado por las «acciones recíprocas» que se dan en la dinámica socializadora. Según Simmel, habría, pues, un componente de repetitividad, de permanencia, que explicaría tanto el origen como la naturaleza de un variado y versátil repertorio de comunidades.

El planteamiento simmeliano posibilita una fecunda lectura de las claves de la lógica que rige el autoreconocimiento colectivo. Michel Maffesoli ha incidido, siguiendo la estela teórica abierta por Simmel, en cómo en las sociedades contemporáneas persiste un elemento tribal directamente ligado al estar juntos (être ensemble) que se materializaría en diferentes contextos de la vida cotidiana. Así. a su juicio, la forma arquetípica, sería un receptáculo de acogida que propiciaría la solidificación de un potencial espíritu de congregación diseminado por diferentes vertientes de la vida cotidiana. Maffesoli insiste, siguiendo a Emile Durkheim, en la existencia de una predisposición re-ligadora que necesita ser saciada y que se reviste de modulaciones variadas. La sociedad contemporánea estimula el despliegue de un abanico de espacios sociales en donde se cumpliría una demanda arquetípica de socialité que favorecería la atracción social. «La forma agrega, reúne, moldea una unicidad, dejando a cada elemento la autonomía que le es propia, constituyendo al mismo tiempo una innegable organicidad, donde sombra y luz, funcionamiento y disfuncionamiento, orden y desorden, lo visible y lo invisible entran en sinergia para generar una estática móvil». ${ }^{39}$ Así pues, la forma, nos dice Maffesoli, es un substrato universal y arquetípico que, en múltiples contextos, sostiene la unión con otros.

Vinculado a lo anterior, la cultura mediática utiliza la imagen como argamasa que favorece la ligazón social. La imagen, lo visible, mantiene una imbricación de fondo con la forma arquetípica, con la matriz de reconocimiento social, en suma, con lo invisible. La imagen mediática, difundida por todo el cuerpo social, posibilitaría la interacción social y, en consecuencia, la cristalización de un vínculo comunitario. En torno al universo de la imagen se cristalizarían, entonces, formas de integración en grupos. Es la visión según la cual, a juicio de Maffesoli, la imagen se torna un componente de corporalidad espiritual. «En efecto, afirma Maffesoli, es por su cercanía por lo que la imagen es vector de comunicación. En este sentido, en oposición a la simple razón que es económica, proyectiva, calculadora, la imagen es ante todo ecológica, se inscribe en un contexto, se vincula a un grupo dado». ${ }^{40}$ Así, la revitalización de la imagen en la cultura actual estaría directamente relacionada al auge de lo local, de lo proxémico, de los espacios de reconocimiento en torno a lo más cercano. ${ }^{41}$ «El recurso epistemológico a la forma, dice Maffesoli, es totalmente pertinente para dar cuenta de una sociabilidad cada vez más estructurada por la imagen». ${ }^{42}$

De este modo, el universo mediático, en sus distintas variantes (cine, televisión, publicidad..), oferta un variado repertorio de imágenes, programas, secuencias, etc.. mediante las cuales se sacia perfectamente la demanda arquetípica de unirse a otros que, en este caso, comparten un similar consumo mediático. La imagen, así, afianza, en cuanto materialización visible en la que se condensa la lógica de la forma, la integración societal. Al coparticipar con otros en la visualización de un mismo programa televisivo, por ejemplo, bien sea éste futbolístico, musical o "grosa», se gestaría una invisible ligazón con otros que comparten un similar gusto o sensibilidad. Los mass-media contribuyen, de esta manera, 
a conformar lazos de unión, más allá de la distancia espacial. El seguimiento cotidiano de una determinada serie o programa televisivo propicia la consolidación de un particular vínculo con otros seguidores, convirtiéndose en un pretexto que sirve para forjar unas formas de relación cotidianas que discurren por cauces alternativos a lo estrictamente contractual o institucional. En buena medida, el éxito de ciertos programas televisivos radica en su capacidad para llegar a estimular formas de sociabilidad o para llegar a articularse con unas formas de sociabilidad ya existentes. Los mass-media, en realidad, simplemente facilitan el espacio para que se despliegue una sociabilidad que en otro tipo de sociedades se fijaba a unas localizaciones específicas. En suma, los medios responden, aunque sea en un nuevo decorado histórico, a las demandas de sociabilidad que emanan del cuerpo social.

Esto se va a manifestar, especialmente, en el dominio de las recientes redes electrónicas. Éstas, favoreciendo la interacción a distancia, sirven, en realidad, como soporte, como continente de acogida, de unos nuevos modelos de socialización. En lo sustancial, el mundo de lo virtual ofrece ahora un espacio inmaterial que sirve como asidero para la cristalización de una socialité, respondiendo, así, a la demanda arquetípica formal de unirse a otros y compartir experiencias análogas. De manera que el vínculo, entonces, que une a los integrantes de un indefinido número de comunidades virtuales va a ser la coparticipación en un mundo imaginario común que existe con independencia de lo espacial. En última instancia, esto muestra la versatilidad del arquetipo formal, su capacidad para llegar a acompasarse con los acelerados cambios que afectan a las tecnologías de la comunicación; aun cuando, conviene no olvidarlo, su naturaleza fundamental sea siempre la misma. ${ }^{43}$

LO NO-RACIONAL El decurso de la cultura occidental está caracterizado por un creciente proceso de racionalización que coloniza las distintas vertientes de la vida social. La arqueología de la modernidad llevada a cabo por autores como Michel Foucault ${ }^{44}$ o Norbert Elias ${ }^{45}$ nos ha mostrado en un caso cómo esta racionalización se encuentra directamente ligada al ejercicio de un poder normalizador y disciplinante y en el otro cómo implica un paulatino autocontrol y regularización de los hábitos y de las costumbres. A raíz de la época moderna, se introduce en Occidente, pues, una visión racional de la existencia. A partir de ella, la totalidad de la vida social podría y debería plegarse a un uniformizador esquema racional. Así, la racionalización acaba por yuxtaponerse sobre la vida, tratando de controlarla y gestionarla desde un modelo externo a ésta.

Esta racionalización conlleva, sin embargo, un consiguiente proyecto de dominación de aquellas instancias de la vida social difícilmente constreñibles a esta hegemónica racionalidad. El psicoanálisis ya se ha encargado de diagnosticar el lado oscuro que se adivina tras la apariencia del sujeto racional, ya ha puesto de manifiesto el inherente conflicto nacido de la represión de la faceta instintiva del ser humano. Existe un ámbito a-racional de la vida, tanto individual como colectiva, que se resiste al plegamiento racional y que retorna constantemente para revelársenos bajo diferentes patologías sociales. Para decirlo en los términos acuñados por Georges Bataille, existe una parte maldita, ${ }^{46}$ un elemento heterogéneo, ${ }^{47}$ que ha sido anatemizado y marginado intencionadamente del horizonte cultural de las sociedades occidentales.

Este terreno no-racional de la vida individual y colectiva lo constituiría todo aquello que, por su propia naturaleza, se resiste a ser pertrechado en un orden racional, es decir, lo propiamente pasional, lo afectivo, lo emocional, o si se quiere, desde una óptica psicoanalítica, el componente propiamente pulsional. Las sociedades tradicionales atesoraban unas estrategias culturales por medio de las cuales lo no-racional jugaba un papel esencial en la propia configuración de su propia idiosincrasia. Lo no-racional era reconocido, era fijado a una ubicación y se mantenía con éste una relación de retroalimentación que revitalizaba el dinamismo social ${ }^{48}$ No era, por tanto exiliado, ocultado y soterrado del espectro de lo social. El espacio de la fiesta constituía el momento concreto en el que lo no-racional se incorporaba a la vida social, en el que el transcurso de la vida cotidiana era suspendido para dar paso a una dimensión temporal distinta. ${ }^{49}$ La instauración de la modernidad, sin embargo, provocará una cruzada frente a ese elemento no-racional que en su despliegue podría llegar a poner en peligro la lógica racional por aquella auspiciada. En consecuencia, a partir de entonces, lo no-racional se percibirá como algo desasosegante y amenazante del orden natural de las cosas.

Esto no significa que estos elementos que extralimitan lo racional hayan sido finalmente sepultados. Por el contrario, la distancia frente a éstos no ha conseguido, en absoluto, evacuarlos del trasfondo de la vida colectiva. La dialéctica racional/a-racional es una dialéctica arquetípica, y por lo tanto universal, que existe en todo tipo de sociedades. Las sociedades actuales, no obstante, al no mirar cara a cara a lo a-racional, están condenadas a que éste rebrote a través de los intersticios que deja la encorsetadota reja racional que trata de controlar y administrar la vida. De este modo, el deseo de alteridad, el ansia de retorno a lo no-civilizado, el reencuentro con lo pasional y emocional, buscan denodadamente nuevos espacios por donde aflorar. En una sociedad dominada por un hipertrófico racionalismo, crece, lógicamente, una asfixiante demanda, a veces tornada hacia lo mórbido, compensatoria de inmersión en lo no-racional.

El encanto provocado por los mass-media en la 
cotidianeidad está estrechamente ligado a la demanda anterior. Buena parte del éxito social de un programa televisivo, de un anuncio publicitario o de un acontecimiento deportivo tiene que ver con una más o menos traslucida oferta de ese repudiado elemento no-racional. En este sentido, los medios sacian, una vez más, un componente arquetípico que pugna por emerger. Los mass-media consiguen atraer y conectarse con esa latente y persistente sed de escapar a un universo plenamente racionalizado, cuya exteriorización cotidiana va a ser una férrea burocratización, planificación y asepsia. El magnetismo suscitado por un insinuador erotismo, la pasión desencadenada en un partido futbolístico, la emoción amorosa sin trabas, nos devuelven el contacto con aquellas dimensiones de la experiencia humana que no tienen cabida en un mundo racionalizado. En última instancia, es el deseo, más o menos consciente, de transgredir y de violentar una vida desposeída de lo más genuinamente vital lo que va a ser estimulado por el universo mediático. Los massmedia satisfacen, así, un acuciante anhelo por traspasar los límites de un mundo racionalizado, una irrefrenable ansia por abrirse a una faceta oscura e inexplorada de la experiencia social en donde se adivinaría al mismo tiempo el peligro y la intensidad de la vida.

\section{A modo de conclusión}

En este trabajo, se pretende reconsiderar la relación existente entre los mass-medias y la sociedad desde una nueva perspectiva, modificando la óptica tradicional de análisis de los medios. Se busca enfatizar que, además de la indudable influencia ideológica de los mass-media, también lo social solicita, en sentido inverso, unas demandas al universo mediático que éste último trataría de satisfacer. Esto implica adentrarnos en el examen de ciertas constantes antropológicas arquetipales que se repiten en todas las culturas y que van a jugar un papel decisivo en la recepción social de los medios. Así, en esta lectura, se han procurado superar las insuficiencias albergadas en la tradicional tesis que concibe la sociedad como un espacio completamente manipulado por una conspiración mediática y víctima de una falsa conciencia generalizada. Hemos indagado, en esta línea, un cudruple registro arquetípico prioritario: lo imaginario, lo mítico, la sociabilidad y lo no-racional; lo que nos ha posibilitado desvelar qué es aquello que, en última instancia, lo social exige de los medios y por qué lo exige. En la cultura actual, va a ser el universo mediático el que precisamente tratará de saciar esta persistente precondición arquetípica. Evidentemente, los medios explotarán posteriormente estas demandas, individuales y colectivas, para interesados fines, pero porque previamente han surgido del cuerpo social.mFamecos
NOTAS

1. Véase especialmente Theodor Adorno y Max Horkheimer, «La industria cultural» en Dialéctica de la Ilustración, Trotta, Madrid, 1994, pp. 165212. También, en una línea análoga, las aportaciones de Guy Debord, La sociedad del espectáculo, Pretextos, Valencia, 1999; Henri Lefebvre, Critique de la vie quotidienne, L'Arche, París, Vol III, 1981, pp.91-153; Roland Barthes, Mitologías, Siglo XXI, Madrid, 1999 y Jean Baudrillard, La société de consommation, Denoël, París, 1970, pp. 147 y ss.; Simulacres et Simulations, Débats, París, 1981.

2. Para un análisis crítico, desde una pespectiva maffesoliana, de esta concepción de la vida cotidiana, véase nuestro trabajo, Enrique Carretero Pasin, «La quotidienneté comme objet. Michel Maffesoli et Henri Lefebvre: Deux lectures opposées», Sociétés. Revue des Sciences Humaines et Sociales, nº78, 2003, pp. 5-17.

3. Para un acercamiento al concepto de hegemonía gramsciano véase Q. Hoare y G. Nowel Smith, Selections from the prison Notebooks, Londres, 1971; Manuel Sacristán, Antología de textos de Antonio Gramsci, Akal, México, 1974; Raymons Williams, Marxismo y literatura, Península, Barcelona, 1997.

4. Véase Louis Althusser, «Ideología y Aparatos ideológicos del Estado en Posiciones», Anagrama, Barcelona, 1971; «Notas sobre los Aparatos ideológicos del Estado» en Nuevos escritos, Laia, Barcelona, 1978.

5. Véase Gerard Imbert, Los escenarios de la violencia, Icaria, Barcelona, 1992, pp. 9-44. Véase, también, Georges Balandier, El poder en escenas, Paidós, Barcelona, 1994, pp. 151-184.

6. Véase, Enrique Carretero Pasin, Imaginarios sociales y crítica ideológica, Servicio de Publicaciones de la Universidad de Santiago de Compostela, 2001; «El poder de los imaginarios sociales. Una reflexión filosófico-sociológica en torno a la legitimación de la dominación en las sociedades postmodernas», Comunicación y Sociedad. Universidad de Guadalajara (México), no 39, 2002, pp. 45-63. También, véase, Blanca Muñoz, «Ideología y dominación simbólica en el modelo cultural postindustrial: para un proyecto teórico y temático de semiología crítica» en Semiología Crítica. De la historia del sentido al sentido de la historia, Anthropos, Barcelona, $n^{\circ}$ 186, 2000, pp. 57-73.

7. John B. Thompson, Ideology and modern culture. Critical social theory in the era of mass communication, Cambridge Polity Press, 1990, p. 95 y ss. 
8. Karl Marx, La ideología alemana, Grijalvo, Universidad de Valencia, 1975, p. 58.

9. Adorno y Horkheimer, «La industria cultural» en Dialéctica de la Ilustración, Trotta, Madrid, 1994, p. 166.

10. El exponente más emblemático de esta versión de lo cotidiano se puede encontrar en Henri Lefebvre, Critique de la vie quotidienne, L'Arche, Paris, 1981, Vol. III. También puede encontrarse la misma perspectiva en el análisis de los mitos publicitarios llevado a cabo por Roland Barthes en Mitologías, Siglo XXI, Madrid, 1999.

11. Jean Baudrillard, Pour une crItique de l'economie polítique du signe, Gallimard, París, 1972.

12. Karl Marx, La cuestión judía, FCE, México, p. 468.

13. La formulación de esta noción de arquetipo puede encontrarse en Kar Gustav Jung, Arquetipos e inconsciente colectivo, Paidós, Buenos Aires, 1977; Mircea Eliade, Imágenes y símbolos, Taurus, Madrid, 1999; El mito del eterno retorno, Alianza, Madrid, 2000 y Gilbert Dürand, Las estructuras antropológicas de lo imaginario, Taurus, Madrid, 1981; De la mitocrítica al mito análisis, Anthropos, Barcelona, 1993. Una aplicación interesante de esta noción al campo de la vida cotidiana puede encontrarse en Emma León Vega, De filias y arquetipos. La vida cotidiana en el pensamiento moderno en Occidente, Anthropos, Barcelona, 2001.

14. A. Sauvageot, Figures de la publicité, figures du monde, PUF, Paris, 1987.

15. Gilbert Dürand, Las estructuras antropológicas de lo imaginario, Taurus, Madrid, 1981, pp. 359-409.

16. Henri Corbin, La imaginación creadora en el sufismo de Ibnl'Arabî, Destino, Barcelona, 1993, pp. 209-284.

17. Rogerd Bastide, El sueño, el trance y la locura, Amorrortu, Buenos Aires, 1972, pp. 32-65.

18. “Nada más frágil - afirma Clement Rosset - que la facultad humana de admitir la realidad, de aceptar sin reservas la imperiosa prerrogativa de lo real" (Rosset, 1993: 9). De ahí, surge, precisamente, la naturaleza de la ilusión, como un estado intermedio entre el absoluto rechazo y la plena admisión de la realidad. "En la ilusión, dice Rosset, es decir, en la manera más corriente de apartar lo real, no hay rechazo de la percepción propiamente dicho. No se niega la cosa, tan sólo se la desplaza, se la coloca en otra parte. Pero, en lo que concierne a la aptitud de ver, el iluso ve, a su manera, tan claramente como cualquier otro" (Rosset, 1993: 12-13).

19. Edgar Morin, El cine o el hombre imaginario, Paidós, Barcelona, 2001.

20. Edgar Morin, l'Esprit du temps, Livre de Poche, Paris, 1981.

21. Ibid., p. 91.

22. Ibid., p. 103.

23. Michel Maffesoli, La conquête du présent. Pour une sociologie de la vie quotidienne, Desclée de Brouwer, Paris, 1998, p. 152.

24. Véase, Federico, Casalegno, (coord.), Technoliens, Sociétés. Revue des Sciences Humaines et Sociales, $n^{\circ} 68,2000$.

25. Roland Barthes, Mitologías, Siglo XXI, Madrid, 1999, p. 237.

26. Henri Bergson, Las dos fuentes de la moral y de la religión, Tecnos, Madrid, 1996, p. 250.

27. Celso Sánchez Capdequí, Imaginación y sociedad. Una hermenéutica creativa de la cultura, Tecnos, Madrid, 1999, p. 170.

28. Theodor Adorno y Max Horkheimer, «El Concepto de Ilustración en Dialéctica de la Ilustración», Trotta, Madrid, 1994, pp. 59-95.

29. Edgar Morin, El MétodoIV, Cátedra, Madrid, 1998, p. 255.

30. Claude Rivière, «Mithes modernes au cœur de l'ideologie», Cahiers Internationaux de Sociologie, Vol. XC, 1991.

31. Mircea Eliade, Aspectos del mito, Paidós, Barcelona, 2000, pp. 155-163.

32. Ibid., p. 163.

33. Raymond Ledrut, Le forme et le sens dans la société, Meridiens, París, 1984, 155-173.

34. Ignacio Gómez de Liaño, «Imágenes y mitos como factores sociológicos» en La mentira social. Imágenes, mitos y conductas, Tecnos, Madrid, 1994, p. 120.

35. Edgar Morin, Les Stars, Éditions du Seuil, París, 1972. 
36. Gillo Dorfles, Nuevos mitos, nuevos ritos, Lumen, Barcelona, 1973, pp. 13-85.

37. «La seducción de las estrellas» en La mentira social. Imágenes, mitos y conducta, Tecnos, Madrid, 1994, p. 167-168.

38. Georg Simmel, Cuestiones fundamentales de sociología, Gedisa, Barcelona, 2002, p. 78-79.

39. Michel Maffesoli, Elogio de la razón sensible, Paidós, Barcelona, 1996, p. 118.

40. Michel Maffesoli, Au creux des apparences. Pour une éthique de l'esthétique, Grasset, Paris, 1992, p.113.

41. Michel Maffesoli, El tiempo de las tribus, Icaria, Barcelona, 1990, p. 238.

42. Michel Maffesoli, Elogio de la razón sensible, Paidós, Barcelona, 1996, p. 141.

43. Véase, Patrick Schmoll, «Les mondes virtuels, entre imagerie et imaginaire» en Fait social et certitudes imaginaires, Sociétés. Revue des Sciences Humaines et sociales, n70, 2000, pp. 35-46.

44. Michel Foucault, Vigilar y castigar, Siglo XXI, Madrid, 1994, pp. 139-233.

45. Norbert Elias, El proceso de la civilización, FCE, México, 1993, pp. 99-253.

46. Georges, Bataille, La parte maldita, Icaría, Barcelona, 1987, pp. 11-47.

47. Georges Bataille, El estado y el problema del fascismo, Pretextos, Valencia, 1993.

48. Véase, Michel Maffesoli, De la orgía. Una aproximación sociológica, Ariel, Barcelona, 1996.

49. Roger Callois, El hombre y lo sagrado, FCE, México, 1996, pp. 109-145.

\section{REFERÊNCIAS}

ADORNO Theodor y Horkheimer, Max Dialéctica de la Ilustración, Trotta, Madrid, 1994.

ALTHUSSER, Louis. «Ideología y Aparatos ideológicos del Estado» en Posiciones, Anagrama, Barcelona, 1971.

«Notas sobre los Aparatos ideológicos del Estado» en Nuevos escritos, Laia, Barcelona, 1978.
BALANDIER, Georges, El poder en escenas, Paidós, Barcelona, 1994.

BARTHES, Roland, Mitologías, Siglo XXI, Madrid, 1999.

BASTIDE, Bastide, El sueño, el trance y la locura, Amorrortu, Buenos Aires, 1972.

BAUDRILLARD, Jean, La société de consommation, Denoël, París, 1970.

—. Pour une critique de l'economie politique du signe, Gallimard, París, 1972.

—. Simulacres et Simulations, Débats, París, 1981.

BERGSON, Henri, Las dos fuentes de la moral y de la religión, Tecnos, Madrid, 1996.

CALLOIS, Roger, El hombre y lo sagrado, FCE, México, 1996.

CARRETERO PASIN, Angel Enrique, Imaginarios sociales y crítica ideológica, Universidad de Santiago de Compostela, 2001.

—_ «El poder de los imaginarios sociales. Una reflexión filosófico-sociológica en torno a la legitimación de la dominación en las sociedades postmodernas», en Comunicación y Sociedad. Universidad de Guadalajara (México), nº 39, 2002.

__ «La quotidienneté comme objet. Michel Maffesoli et Henri Lefebvre: Deux lectures opposées». Sociétés. Revue des Sciences Humaines et Sociales, nº78, 2003.

CASALEGNO, Federico (coord.), Technoliens, Sociétés. Revue des Sciences Humaines et Sociales, $n^{\circ} 68,2000$.

CORBIN, Henri, La imaginación creadora en el sufismo de Ibnl'Arabî, Barcelona, Destino, 1993.

DEBORD, Guy, La sociedad del espectáculo, Pretextos, Valencia, 1999. Dorfles, Gillo, Nuevos mitos, nuevos ritos, Lumen, Barcelona, 1973.

DURAND, Gilbert, Las estructuras antropológicas de lo imaginario, Taurus, Madrid, 1981.

—. De la mitocrítica al mito análisis, Anthropos, Barcelona, 1993.

ELIADE, Mircea, Imágenes y símbolos, Taurus, Madrid, 1999. 
_. El mito del eterno retorno, Alianza, Madrid, 2000.

—. Aspectos del mito, Paidós, Barcelona, 2000.

ELIAS, Norbert, El proceso de la civilización, FCE, México, 1993.

FOUCAULT, Michel, Vigilar y castigar, Siglo XXI, Madrid, 1994.

GÓMEZ DE LIAÑO, Ignacio, La mentira social. Imágenes, mitos y conductas, Tecnos, Madrid, 1994.

HOARE, Q. y Nowel Smith, G. Selections from the prison Notebooks, Londres, 1971.

IMBERT, Gerard, Los escenarios de la violencia, Icaria, Barcelona, 1992.

JUNG, Karl Gustav, Arquetipos e inconsciente colectivo, Paidós, Buenos Aires, 1977.

LEDRUT, Raymond, Le forme et le sens dans la société, Meridiens, Paris, 1984.

LEFEBVRE, Henri, Critique de la vie quotidienne, L'LArche, Paris, Vol I (1968) - III (1981).

LEÓN VEGA, Enma, De filias y arquetipos. La vida cotidiana en el pensamiento moderno en Occidente, Anthropos, Barcelona, 2001.

MAFFESOLI, Michel, El tiempo de las tribus, Icaria, Barcelona, 1990.

— . De la orgía. Una aproximación sociológica, Ariel, Barcelona, 1996.

_. La conquête du présent. Pour une sociologie de la vie quotidienne, Desclée de Brouwer, Paris, 1998.

—. Au creux des apparences. Pour une éthique de l'Lesthétique, Grasset, Paris, 1992.

—_. Elogio de la razón sensible, Paidós, Barcelona, 1996.

MARX, Karl, La ideología alemana, Grijalvo, Universitat de Valencia, 1975.

—. La cuestión judia, FCE, México, 1982.

MORIN, Edgar, Les Stars, Éditions du Seuil, Paris, 1972.

— L Le Sprit du temps, Livre de Poche, Paris, 1981.
—_. El MétodoIV, Cátedra, Madrid, 1998.

_. El cine o el hombre imaginario, Paidós, Barcelona, 2001.

MUÑOZ, Blanca, «Ideología y dominación simbólica en el modelo cultural postindustrial: para un proyecto teórico y temático de semiología crítica» en Semiología Crítica. De la historia del sentido al sentido de la historia, Anthropos, Barcelona, nº 186, 2000.

RIVIERE, Claude, «Mithes modernes au cœur de l'ideologie», Cahiers Internationaux de Sociologie, Vol. XC, 1991.

ROSSET, Climent, Lo real y su doble. Ensayo sobre la ilusión, Tusquets, Barcelona, 1993.

SACRISTÁN, Manuel, Antología de textos de Antonio Gramsci, Akal, México, 1974.

SÁNCHEZ CAPDEQUÍ, Celso, Imaginación y sociedad. Una hermenéutica creativa de la cultura, Tecnos, Madrid, 1999.

SAUVAGEOT, A. Figures de la publicité, figures $d u$ monde, PUF, Paris, 1987.

SCHMOLL, Patrick, «Les mondes virtuels, entre imagerie et imaginaire» en Fait social et certitudes imaginaires, Sociétés. Revue des Sciences Humaines et sociales, Paris, $\mathrm{n}^{\mathrm{0} 70}$, 2000.

SIMMEL, Georg, Cuestiones fundamentales de sociología, Gedisa, Barcelona, 2002.

THOMPSON, John B., Ideology and modern culture. Critical social theory in the era of mass communication, Polity Press, Cambridge, 1990.

WILLIAMS, Raymond, Marxismo y literatura, Península, Barcelona, 1997. 